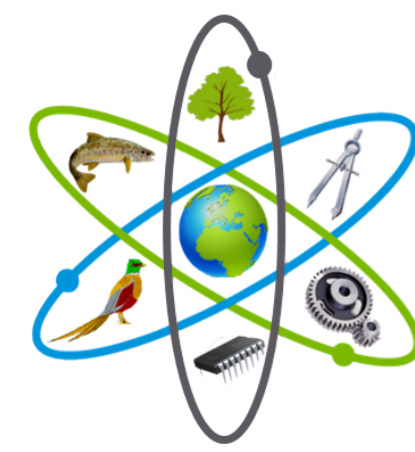

\title{
Natural and Engineering Sciencers
}

NESciences, 2021, 6(1): 19-29

Doi: $10.28978 /$ nesciences. 868061

\section{Azo dye decolorization by using four different psychrotolerant Bacillus species}

\author{
Muhsin Aydın ${ }^{*}$, AD Alişan Ağaoğlu² iD, Özlem Barış ${ }^{3}$ iD \\ ${ }^{* 1}$ Dept. of Biology, Faculty of Science and Letters, Adiyaman University, Adiyaman, Turkey \\ ${ }^{2}$ Dept. of Biology, Graduate School of Natural and Applied Sciences, Atatürk University, \\ Erzurum, Turkey \\ ${ }^{3}$ Dept. of General Biology, Faculty of Science, Atatürk University, Erzurum, Turkey
}

\begin{abstract}
Since the early ages, human beings have used colored materials to leave marks on their environment and the following generations. In time, paints, which gained great importance with painting the objects and the items they used, brought environmental problems with them. Synthetic paints/dyes used to meet the increasing need over time had to be eliminated from the environment. Nowadays, using bacteria is considered as a good solution for eliminating dyes that contain azo groups. These dyes are used in large quantities and difficult to decompose. The main goal of this study was to decolor six different (amido black 10B, evans blue, janus green, methyl orange, methyl red, and orange $\mathrm{G}$ ) azo dyes by use of four different psychrotolerant Bacillus (Bacillus sp, B. cereus, B. mycoides, and B. subtilis) isolates. According to the obtained results, it was determined that the psychrotolerant Bacillus isolates could remove colors of the six azo dyes by presenting high decolorization activity (up to $98 \%$ ).
\end{abstract}

\section{Keywords:}

Azo dyes; Bacillus spp., Color removal, Decolorization, Psychrotolerant

\section{Article history:}

Received 19 August 2020, Accepted 17 January 2021, Available online 25 January 2021

\section{Introduction}

Today, azo dyes are used today in many fields, including textile, plastic, and paper industries (Sudha et al., 2014). Dye-contaminated water, especially from the dyeing processes in the textile industry, is discharged with the waste water of the textile factories. The dyeing of wastewater results from dyeing the textile products, adding prints on the products, and washing the products. The paint level of water depends on the density and the structure of the dyestuff (Fu \& Viraraghavan, 2000). Discharging textile industry wastewater to the environment causes undesirable environmental conditions that are not suitable for human, animal, and plant health

\footnotetext{
* Corresponding Author: Muhsin AYDIN, E-mail: muhsin.aydin@live.com
} 
(Chung \& Stevens, 1993). This may result in putting many wild species in danger of being extinct. When natural dyes are compared to synthetic dyes, the use of synthetic dyes is increasing day by day because they have different color choices. Synthetic paints are used in many fields such as cosmetics, food, and textiles (Aksu, 2005). The majority of commercially used synthetic dyes are toxic and carcinogenic and consist of azo dyes that can cause changes in genes (Seesuriyachana et al., 2007). These dyes have significant accumulation properties in nature because they are resistant to disintegration thanks to their azo bonds. Azo compounds are chemically represented as $\mathrm{R}-\mathrm{N}=$ $\mathrm{N}-\mathrm{R}$, where $-\mathrm{N}=\mathrm{N}$ - is the azo group, and the $\mathrm{R}$ or $\mathrm{R}^{\prime}$ can be either aryl or alkyl compounds (Chung, 2016). Azo dyes are stable in acidic and alkaline conditions, do not decompose in an oxygenated environment, and are resistant to heat and light. Due to these features, azo dyes cannot be purified and/or eliminated by standard treatment methods. Sometimes, a reactive dye cannot be eliminated from water and discharged to the waste water drainage system by contaminating the water in a high concentration that could be $90 \%$ (Lucas et al., 2007). In addition to both physical and chemical methods, various removal techniques can also be used to remove these dyes (Sun et al., 2007). Among these methods, biological methods have gained more popularity recently. Primarily, use of microorganisms, which can break down azo dyes in aerobic or anaerobic conditions, have been preferred (Jamie \& Siddique, 2019).

It is clear that the investigation of the effects of azo dyes on public health will be one of the most important strategies in preventing many diseases, especially cancer (Chung, 2016). In this study, it was aimed to use psychrotolerant bacteria in the removal of azo dyes color that could be found in waste waters. For this purpose, methyl red, methyl orange, orange g, amido black 10b, evans blue, janus green paints were used and color removals in these dyes were measured using a spectrophotometer with the help of four different and psychrotolerant Bacillus species.

\section{Materials and Method}

\section{Bacillus Strains Used in This Study}

In this study, four different strains belonging to the Bacillus genus were used. These are: B. subtilis, B. mycoides, B. cereus, and Bacillus sp. strains. All strains were obtained from Özlem Barış, who works at Atatürk University, Faculty of Science, Department of Biology, Microbiology Laboratory. These bacteria were isolated from the caves of Erzurum province and their development temperatures were determined as $7-45^{\circ} \mathrm{C}$ and their optimum growth temperature was $30^{\circ} \mathrm{C}(\mathrm{Bar}$ ş, 2009). The cultures used in this study were grown on TSA media by incubating them at $30^{\circ} \mathrm{C}$ for 24 hours.

\section{Azo Dyes Used in This Study}

In this study, six different azo dyes were used. These are Amido Black 10B (EC Apparatus Corporation), Evans Blue (Merck, 5191531), Janus Green (Merck, 9743040, CI Nr 11050), Methyl Orange (Merck, 123602), Methyl Red (Merck, 5279510, CI Nr13020), and Orange G (Merck, 5202928, CI Nr 16230). All of the used dyes are commercially available, and obtained by purchasing them from a local distributor. 


\section{Dye Concentrations Used in This Study}

The dyes used in this study were studied in 5 different concentrations. These concentrations are determined as 10, 20, 50, 100, and $200 \mathrm{mg} / \mathrm{L}$. The concentrations used in this study were determined by considering previous studies (Mishra and Sharma 2014; Lalnunhlimi \& Veenagayathri 2016; Al Hamadi 2017). The dyes are prepared in flasks containing $250 \mathrm{ml}$ of TSB. Preparation of 10,20, 50,100, and $200 \mathrm{mg} / \mathrm{L}$ concentrations were done as follows; 2.5, 5, 12.5, 25, and $50 \mathrm{mg}$ of each dye were weighed for each concentration, respectively. The powdered dyes were dissolved with some distilled water and each of them was transferred to a different flask. Then, $7.5 \mathrm{~g}$ of TSB was weighed and transferred to the flask as instructed by the manufacturer. Distilled water was added slowly in small amounts to complete it to $250 \mathrm{~mL}$.

All Bacillus strains, enlivened in petri prior to use in TSB. TSBs that contain different concentration of the six different azo dyes, are prepared for use by suspending the bacteria aseptically in $10 \mathrm{~mL}$ tubes $(1-2 \times 108 \mathrm{CFU}$ per tube). Subsequently, the samples taken from cultures, which were incubated for 72 hours at $30^{\circ} \mathrm{C}$, were centrifuged at $2,000 \mathrm{rpm}$ for 15 minutes and dye removal was determined by measuring the absorbance values of supernatants (Barış, 2009; Shah, 2014; Guadie et al., 2017). All concentrations were tested as duplicates.

\section{Determination of the Azo Dyes Removal Rates}

In order to determine the rate of decolorization of the used azo dyes, Shah (2014) and Guadie et al. (2017) method has been partially modified and used. Briefly, cultures were centrifuged at 2,000 rpm for 15 minutes. The absorbance values of the obtained supernatants at the wavelength at which the dyestuff give the maximum absorbance were read in the spectrophotometer. Janus green, methyl red, evans blue, amido black 10B, methyl orange, and orange $\mathrm{G}$ were read at $605,430,615$, 618, 466, and $480 \mathrm{~nm}$, respectively. Azo dye removal percentage was determined by calculating the difference between the negative control's (NC) absorbance value and the positive control (PC) concentration's absorbance value after incubation. TSB medium without addition of any dyes and bacteria was used as a blank.

Azo dye decolorization calculation formula:

$$
\text { Decolorization } \%=\frac{N C \text { Abs. }-P C \text { Abs. }}{N C \text { Abs. }} \times 100
$$

\section{Results}

\section{Azo Dye Removal Results of B. cereus}

Color removal results of all tested azo dyes that was made by B. cereus presented in Table 1 . The color reduction rates of janus green azo dye at concentrations of 10,20,50,100, and $200 \mathrm{mg} / \mathrm{L}$ were calculated to be $22 \%, 17 \%, 21 \%, 10 \%$, and $8 \%$, respectively. Likewise, the same concentrations of the methyl red azo dye were decolorized by $31 \%, 28 \%, 26 \%, 43 \%$, and $36 \%$, respectively. Similarly, the same concentrations of the evans blue azo dye were decolorized by $58 \%, 80 \%, 53 \%, 68 \%$, and $0 \%$, respectively. No results were obtained at $200 \mathrm{mg} / \mathrm{L}$ concentration of evans blue. Additionally, amido black $10 \mathrm{~B}$ azo dye was also tested at the same five concentrations and the decolorization rates were $11 \%, 38 \%, 65 \%, 73 \%$, and $63 \%$, respectively. 
Methyl orange and orange $\mathrm{G}$ azo dyes were tested at only 50, 100, and $200 \mathrm{mg} / \mathrm{L}$ concentrations. Their color removal rates were 37\%, 70\%, and 35\%; and 72\%, 58\%, and 36\%, respectively.

\section{Azo Dye Removal Results of B. subtilis}

Color removal results of all tested azo dyes that was made by B. subtilis presented in Table 2 . The decolorization rates were ranged between $3-67 \%$. The color reduction rates of janus green azo dye at concentrations of $10,20,50,100$, and $200 \mathrm{mg} / \mathrm{L}$ were calculated to be $56,25,3,24$, and $8 \%$, respectively. Also, the same concentrations of the methyl red azo dye were decolorized by 13, 35, 19,22 , and $37 \%$, respectively. In the same way, the same concentrations of the evans blue azo dye were decolorized by 67, 60, 32, 37, and 10\%, respectively. As well, amido black 10B azo dye was also tested at the same concentrations and the decolorization rates were $35,42,17,21$, and $8 \%$, respectively. Methyl orange and orange $\mathrm{G}$ azo dyes were tested at only 50, 100, and $200 \mathrm{mg} / \mathrm{L}$ concentrations. Their decolorization rates were 41,39, and 25\%; and 57, 54, and 45\%, respectively.

\section{Azo Dye Removal Results of B. mycoides}

Decolorization results of all tested azo dyes that was made by B. mycoides presented in Table 3 . The decolorization rates were ranged between $7-80 \%$. The color removal rates of janus green azo dye at concentrations of 10,20,50,100, and $200 \mathrm{mg} / \mathrm{L}$ were calculated to be $80,52,24,44$, and $14 \%$, respectively. The same concentrations of the methyl red azo dye were decolorized by 78,53 , 12,7 , and $32 \%$, respectively. Similarly, the same concentrations of the evans blue azo dye were decolorized by $68,69,32,35$, and $12 \%$, respectively. In addition, amido black $10 \mathrm{~B}$ azo dye was also tested at the same five concentrations and the decolorization rates were 49, 47, 46, 25, and $17 \%$, respectively. Both methyl orange and orange $\mathrm{G}$ azo dyes were tested at only 50, 100, and 200 $\mathrm{mg} / \mathrm{L}$ concentrations. The color removal rates of these two dyes were 25,23 , and $31 \%$; and 55, 43, and $44 \%$, respectively.

\section{Azo Dye Removal Results of Bacillus sp.}

Spectrophotometrically measured color removal results of all tested azo dyes that was made by Bacillus sp. presented in Table 4. The decolorization rates were ranged between 3-98\%. The color removal rates of janus green azo dye at concentrations of 10, 20, 50, 100, and $200 \mathrm{mg} / \mathrm{L}$ were calculated to be $18,12,3,21$, and $5 \%$, respectively. The same concentrations of the methyl red azo dye were decolorized by $65,68,46,9$, and $35 \%$, respectively. Likewise, the same concentrations of the evans blue azo dye were decolorized by $94,86,35,40$, and $\% 3 \%$, respectively. Furthermore, amido black 10B azo dye was also tested at the same five concentrations and the decolorization rates were $98,87,59,54$, and $36 \%$, respectively. Both methyl orange and orange G azo dyes were tested at only 50,100, and $200 \mathrm{mg} / \mathrm{L}$ concentrations. The color removal rates of these two dyes were 47,33 , and $8 \%$; and 66,58 , and $47 \%$, respectively. 
Table 1. Decolorization of six azo dyes by B. cereus

\begin{tabular}{|c|c|c|c|c|c|c|c|}
\hline \multirow[b]{2}{*}{$\begin{array}{l}\text { Used azo dyes } \\
\text { (wavelength) }\end{array}$} & \multirow[b]{2}{*}{ Controls } & \multicolumn{6}{|c|}{ Concentrations (mg/L) } \\
\hline & & $\mathbf{0}$ & 10 & 20 & 50 & 100 & 200 \\
\hline Janus Green & $\mathrm{NC}$ & $0 \Omega 40$ & 0.134 & 0.185 & 0.494 & 0.793 & 0.902 \\
\hline$(605 \mathrm{~nm})$ & $\mathrm{PC}$ & 0.040 & 0.105 & 0.155 & 0.394 & 0.718 & 0.831 \\
\hline Methyl Red & $\mathrm{NC}$ & & 0.174 & 0.248 & 0.276 & 0.501 & 0.982 \\
\hline$(430 \mathrm{~nm})$ & $\mathrm{PC}$ & 0.281 & 0.121 & 0.180 & 0.206 & 0.288 & 0.637 \\
\hline Evans Blue & $\mathrm{NC}$ & & 0.080 & 0.093 & 0.199 & 0.235 & 0.333 \\
\hline$(615 \mathrm{~nm})$ & $\mathrm{PC}$ & 0.035 & 0.034 & 0.019 & 0.095 & 0.077 & 0.334 \\
\hline Amido Black 10B & $\mathrm{NC}$ & & 0.047 & 0.056 & 0.073 & 0.129 & 0.241 \\
\hline$(618 \mathrm{~nm})$ & $\mathrm{PC}$ & 0.101 & -0.042 & -0.035 & -0.026 & -0.0035 & 0.09 \\
\hline Methyl Orange & $\mathrm{NC}$ & 0068 & NA & NA & 0.207 & 0.291 & 0.506 \\
\hline$(466 \mathrm{~nm})^{*}$ & $\mathrm{PC}$ & -0.008 & NA & NA & 0.133 & 0.088 & 0.331 \\
\hline Orange G & $\mathrm{NC}$ & 0094 & NA & NA & 0.258 & 0.418 & 0.771 \\
\hline$(480 \mathrm{~nm})^{*}$ & $\mathrm{PC}$ & 0.094 & NA & NA & 0.073 & 0.176 & 0.321 \\
\hline
\end{tabular}

NC: negative control (distilled water $+\mathrm{TSB}+$ azo dye)

PC: positive control (distilled water + TSB + azo dye + psychrophilic B. cereus)

* The results of methyl Orange and Orange $\mathrm{G}$ dyes could not be determined at concentrations of 10 and $20 \mathrm{mg} / \mathrm{L}$.

Table 2. Decolorization of six azo dyes by B. subtilis

\begin{tabular}{|c|c|c|c|c|c|c|c|}
\hline \multirow[b]{2}{*}{$\begin{array}{l}\text { Used azo dyes } \\
\text { (wavelength) }\end{array}$} & \multirow[b]{2}{*}{ Controls } & \multicolumn{6}{|c|}{ Concentrations (mg/L) } \\
\hline & & $\mathbf{0}$ & 10 & 20 & 50 & 100 & 200 \\
\hline Janus Green & $\mathrm{NC}$ & & 0.134 & 0.185 & 0.494 & 0.793 & 0.902 \\
\hline$(605 \mathrm{~nm})$ & $\mathrm{PC}$ & 0.040 & 0.060 & 0.140 & 0.442 & 0.604 & 0.835 \\
\hline Methyl Red & $\mathrm{NC}$ & & 0.174 & 0.248 & 0.276 & 0.501 & 0.982 \\
\hline$(430 \mathrm{~nm})$ & $\mathrm{PC}$ & 0.281 & 0.121 & 0.180 & 0.206 & 0.288 & 0.637 \\
\hline Evans Blue & $\mathrm{NC}$ & 0035 & 0.080 & 0.093 & 0.199 & 0.235 & 0.333 \\
\hline$(615 \mathrm{~nm})$ & $\mathrm{PC}$ & 0.053 & 0.027 & 0.038 & 0.136 & 0.149 & 0.300 \\
\hline Amido Black 10B & $\mathrm{NC}$ & 0107 & 0.047 & 0.056 & 0.073 & 0.129 & 0.241 \\
\hline$(618 \mathrm{~nm})$ & $\mathrm{PC}$ & $0.10 /$ & 0.031 & 0.033 & 0.061 & 0.102 & 0.217 \\
\hline Methyl Orange & $\mathrm{NC}$ & & NA & NA & 0.207 & 0.291 & 0.506 \\
\hline$(466 \mathrm{~nm}) *$ & $\mathrm{PC}$ & -0.068 & NA & NA & 0.124 & 0.180 & 0.383 \\
\hline Orange G & $\mathrm{NC}$ & 0 O० & NA & NA & 0.258 & 0.418 & 0.771 \\
\hline$(480 \mathrm{~nm})^{*}$ & $\mathrm{PC}$ & 0.094 & NA & NA & 0.111 & 0.194 & 0.428 \\
\hline
\end{tabular}

NC: negative control (distilled water + azo dye)

PC: positive control (distilled water + azo dye + psychrophilic B. subtilis)

* The results of methyl Orange and Orange G dyes could not be determined at concentrations of 10 and $20 \mathrm{mg} / \mathrm{L}$. 
Table 3. Decolorization of six azo dyes by B. mycoides

\begin{tabular}{lccccccc}
\hline & & \multicolumn{7}{c}{ Concentrations (mg/L) } \\
$\begin{array}{l}\text { Used azo dyes } \\
\text { (wavelength) }\end{array}$ & Controls & $\mathbf{0}$ & $\mathbf{1 0}$ & $\mathbf{2 0}$ & $\mathbf{5 0}$ & $\mathbf{1 0 0}$ & $\mathbf{2 0 0}$ \\
\hline Janus Green & $\mathrm{NC}$ & \multirow{2}{*}{0.010} & 0.134 & 0.185 & 0.494 & 0.793 & 0.902 \\
$(605 \mathrm{~nm})$ & $\mathrm{PC}$ & & 0.027 & 0.089 & 0.379 & 0.448 & 0.782 \\
Methyl Red & $\mathrm{NC}$ & \multirow{2}{*}{0.272} & 0.174 & 0.248 & 0.276 & 0.501 & 0.982 \\
$(430 \mathrm{~nm})$ & $\mathrm{PC}$ & & 0.040 & 0.119 & 0.244 & 0.468 & 0.672 \\
Evans Blue & $\mathrm{NC}$ & \multirow{2}{*}{0.009} & 0.080 & 0.093 & 0.199 & 0.235 & 0.333 \\
$(615 \mathrm{~nm})$ & $\mathrm{PC}$ & & 0.026 & 0.029 & 0.137 & 0.155 & 0.295 \\
Amido Black 10B & $\mathrm{NC}$ & \multirow{2}{*}{0.045} & 0.047 & 0.056 & 0.073 & 0.129 & 0.241 \\
$(618 \mathrm{~nm})$ & $\mathrm{PC}$ & & 0.024 & 0.030 & 0.040 & 0.097 & 0.201 \\
Methyl Orange & $\mathrm{NC}$ & \multirow{2}{*}{0.051} & $\mathrm{NA}$ & $\mathrm{NA}$ & 0.207 & 0.291 & 0.506 \\
$(466 \mathrm{~nm}) *$ & $\mathrm{PC}$ & & $\mathrm{NA}$ & $\mathrm{NA}$ & 0.156 & 0.225 & 0.351 \\
Orange G & $\mathrm{NC}$ & \multirow{2}{*}{0.083} & $\mathrm{NA}$ & $\mathrm{NA}$ & 0.258 & 0.418 & 0.771 \\
$(480 \mathrm{~nm}) *$ & $\mathrm{PC}$ & & NA & NA & 0.118 & 0.239 & 0.434 \\
\hline
\end{tabular}

NC: negative control (distilled water + azo dye)

PC: positive control (distilled water + azo dye + psychrophilic B. mycoides)

* The results of methyl Orange and Orange $\mathrm{G}$ dyes could not be determined at concentrations of 10 and $20 \mathrm{mg} / \mathrm{L}$.

Table 4. Decolorization of six azo dyes by Bacillus sp.

\begin{tabular}{lccccccc}
\hline & & \multicolumn{7}{c}{ Concentrations (mg/L) } \\
\hline $\begin{array}{l}\text { Used azo dyes } \\
\text { (wavelength) }\end{array}$ & Controls & $\mathbf{0}$ & $\mathbf{1 0}$ & $\mathbf{2 0}$ & $\mathbf{5 0}$ & $\mathbf{1 0 0}$ & $\mathbf{2 0 0}$ \\
\hline Janus Green & NC & -0.016 & 0.134 & 0.185 & 0.494 & 0.793 & 0.902 \\
$(605 \mathrm{~nm})$ & $\mathrm{PC}$ & & 0.111 & 0.163 & 0.482 & 0.634 & 0.862 \\
Methyl Red & NC & 0.517 & 0.174 & 0.248 & 0.276 & 0.501 & 0.982 \\
$(430 \mathrm{~nm})$ & $\mathrm{PC}$ & & -0.061 & 0.071 & 0.150 & 0.460 & 0.589 \\
Evans Blue & NC & 0.021 & 0.080 & 0.093 & 0.199 & 0.235 & 0.333 \\
$(615 \mathrm{~nm})$ & $\mathrm{PC}$ & & 0.005 & 0.026 & 0.134 & 0.142 & 0.324 \\
Amido Black 10B & NC & 0.035 & 0.047 & 0.056 & 0.073 & 0.129 & 0.241 \\
$(618 \mathrm{~nm})$ & $\mathrm{PC}$ & & 0.001 & 0.025 & 0.030 & 0.060 & 0.180 \\
Methyl Orange & NC & -0.061 & NA & NA & 0.207 & 0.291 & 0.506 \\
$(466 \mathrm{~nm}) *$ & PC & & NA & NA & 0.119 & 0.169 & 0.485 \\
Orange G & NC & 0.129 & NA & NA & 0.258 & 0.418 & 0.771 \\
$(480 \mathrm{~nm})^{*}$ & PC & & NA & NA & 0.090 & 0.176 & 0.409 \\
\hline
\end{tabular}

NC: negative control (distilled water + azo dye)

PC: positive control (distilled water + azo dye + psychrophilic Bacillus sp.)

* The results of methyl Orange and Orange G dyes could not be determined at concentrations of 10 and $20 \mathrm{mg} / \mathrm{L}$.

\section{Discussion}

The importance of environmental pollution control is increasing. Dyestuffs may have toxic effects or even mutagenic and genotoxic effects when spread in the environment or mixed with soil, plants, 
animals and eventually foods and drinks in various ways. In this regard, it is important to remove the dyes that can harm the environment and living ecosystems in a harmless way, especially biologically (Jo-Shu et al, 1989; Leelakriangsak \& Borisut 2012). In the past two decades, biological elimination of the azo dyes is preferred due to their lower cost and does not create toxic products in environments, and it is the most recommended dye removal method by several studies (Silveria et al., 2003; Shah et al. 2013b; Boustanabadimaralan 2014; Sghaier et al., 2019).

Therefore, in this study, the color removal capability of four different psychrophilic/psychrotolerant strains belonging to Bacillus genus, which are natural dye removers, was investigated on six azo dyes. As presented in tables 1-4, the decolorization rates of the tested Bacillus species varied and the maximum rate was $98 \%$.

Bacillus cereus, which was used in this study, has also been used by different researchers in dye removal process (Deng et al., 2008; Liao et al., 2013; Shah et al., 2013b; Madhuri et al., 2018). Deng et al. (2008), isolated B. cereus DC11 strain from active sludge left from the treatment of textile printing wastewater and tested it on 13 different azo dyes. The researchers observed that the strain they isolated had a high color-removing effect on all 13 azo dyes. Similarly, in our study, $B$. cereus was tested on removal of the six different azo dyes, and it was found to decolorize the used dyes 8 to $73 \%$ in different concentrations in all of these dyes. Likewise, Liao et al. (2013) determined that $B$. cereus $\mathrm{HJ}-1$ strain was able to remove reactive black B azo dye. In another study, Shah et al. (2013b) tested azo dye removal with B. cereus and B. megaterium and they reported that the biological removal of azo dyes used in textile can be possible. Madhuri et al. (2018) showed that biodegradation of remazol red RB azo dye can be possible with B. cereus. The results of all the mentioned studies are consistent with the results of our study. In another similar study, B. cereus and B. subtilis were shown to remove azo dyes at the rates of $49 \%$ and $72 \%$, respectively (Gomaa, 2016).

Leelakriangsak \& Borisut (2012) tested B. subtilis azo-reductase activity on four different azo dyes and found that this bacterium was effective in azo dye removal by rates between 40-98\%. This result is compatible with the current study. Results of this study indicated that the decolorization rate of $B$. subtilis on 6 different azo dyes varies between $8 \%$ and $67 \%$. However, the difference in color removal between our study and Leelakriangsak \& Borisut (2012) study could be resulted from different incubation temperatures. The researchers incubated their strain at $25^{\circ} \mathrm{C}$ while we incubated them at $30{ }^{\circ} \mathrm{C}$. In another study, Kumar et al. (2015) measured the biodegradative capacity of $B$. subtilis on four different azo dyes and showed that it was between 6 and $96 \%$. These results are in accordance with the current study. Shah et al. (2013a) investigated the removal effect of $B$. subtilis ETL-2211 strain on the crystal violet dye and observed that it was effective at $35^{\circ} \mathrm{C}$. Unlike our study, although they kept the incubation temperature higher, they obtained similar results with our study.

In this study, it was determined that $B$. mycoides removed color in different concentrations of six different azo dyes at rates ranging from 3\% to 80\%. Mahmood et al. (2015) reported that bacteria can be effective in the consortium of six different bacterial species isolated from the textile wastewater zone in the removal of azo dye degradation, all of the four bacterial species that were used in this study are among the consortium. Although bacteria have not been individually tested, $66.7 \%$ of the bacteria in the used consortium are the same species that tested in this study. The results of Mahmood et al. (2015) can be considered as compatible with our study. Thakur et al. 
(2012) found the presence of $B$. mycoides among the bacteria isolated from the wastewater systems of textile and dye factories. However, to best of our knowledge, spectrophotometric studies on azo dye removal by use of $B$. mycoides alone have not been carried out yet. This increases the importance of this study. Additionally, it was thought that this study will serve as a reference to the dye removal studies by use of B. mycoides that will be done in the future.

In the present study, the azo dye removal tests with Bacillus sp. suggested that this bacterium achieved a success rate of up to $98 \%$ in different concentrations. In contrast, Leelakriangsak \& Borisut (2012) achieved negative results in their study in which Bacillus sp. tested on two different azo dye removal. The reason for this could be the use of different dyes for testing the bacterium. On the other hand, Guadie et al. (2017) tested Bacillus sp. CH12 strain biodecolorization property of on a textile azo dye and noted that Bacillus sp. had a high potential of decolorization activity. This result is coherent with the current study. In addition, Dawkar et al. (2010) determined that dye removal can be done within 24 hours by use of Bacillus sp. VUS strain. This result coincides with the results obtained from our study. In another study, Jaiswal et al. (2014) concluded that Bacillus sp. is effective in removing malachite green and indigo carmine azo dyes as a result of their experimental data, which suggested that the use of Bacillus sp. strains could be beneficial in removing azo dye from the environment. The majority of the studies mentioned above are in harmony with this study and show that Bacillus sp. has a strong azo dye removal potential.

In conclusion, the results obtained in this study revealed that the psychrotolerant B. cereus, B. subtilis, B. mycoides, and Bacillus sp. can be useful in the industry. However, there is a need for molecular and biochemical research involving more advanced techniques to illuminate the mechanisms related to the color removal capabilities of the used four different Bacillus spp. used in this study. It was thought that the findings obtained in our study can be taken as a basis for future studies.

\section{Acknowledgements}

This study is a part of Alişan AĞAOĞLU's master thesis.

\section{Author Contributions}

All author contributions are equal for the preparation research in the manuscript.

\section{Data Availability Statement}

The data that support the findings of this study are available on request from the corresponding author.

\section{Conflict of Interest}

The authors declare that they have no conflict of interest.

\section{References}

Aksu, Z. (2005). Application of biosorption for the removal of organic pollutants: a review. Process Biochemistry, 40:997-1026. 
Al Hamadi, A., Uraz, G., Katırcıoğlu, H. \& Osmanağaoğlu, Ö. (2017). Adsorption of azo dyes from textile wastewater by Spirulina platensis. Eurasian Journal of Environmental Research, 1 (1):19-27.

Barış, Ö. (2009). Erzurum ilindeki mağaralarda damlataşı oluşumunda etkili bakterilerin izolasyonu, karakterizasyonu ve tanısı. Doctoral Thesis, Atatürk Üniversitesi, Fen Bilimleri Enstitüsü, Erzurum, Turkey.

Boustanabadimaralan, N. (2014). Bacillus thuringiensis ile çeşitli boyaların renk giderimlerinin araştırılması. Master Thesis, Hacettepe Üniversitesi, Fen Bilimleri Enstitüsü, Ankara, Turkey.

Chung, K. T. \& Stevens, S. E. (1993). Degradation of azo dyes by environmental microorganisms and helminths. Environmental Toxicology and Chemistry, 12:2121- 2132.

Chung, K. T. (2016). Azo dyes and human health: A review, Journal of Environmental Science and Health, Part C, 34(4):233-261.

Dawkar, V. V., Jadhav, U. U., Tamboli, D. P. \& Govindwar, S. P. (2010). Efficient industrial dye decolorization by Bacillus sp. VUS with its enzyme system. Ecotoxicology and Environmental Safety, 73(7):1696-1703.

Deng, D., Guo, J., Zeng, G., \& Sun, G. (2008). Decolorization of anthraquinone, triphenylmethane and azo dyes by a new isolated Bacillus cereus strain DC11. International Biodeterioration and Biodegradation, 62:263-269.

Fu, Y. \& Viraraghavan, T. (2000). Fungal decolorization of dye wastewaters: a review. Bioresource Technology, 79:251-262.

Gomaa, E.Z. (2016). Biodegradation and detoxification of azo dyes by some bacterial strains. Microbiology Journal, 6(1-2):15-24.

Guadie, A., Tizazu, S., Melese, M., Guo., W., Ngo, H. H. et al. (2017). Biodecolorization of textile azo dye using Bacillus sp. strain $\mathrm{CH} 12$ isolated from alkaline lake. Biotechnology Reports, 15:92-100.

Jaiswal, S., Gomashe, A.V. \& Agrawal, S., (2014). Decolorization potential of Bacillus sp. for removal of synthetic textile dyes. International Journal of Current Microbiology and Applied Sciences, 3(12):83-88.

Jamee, R. \& Siddique, R. (2019). Biodegradation of synthetic dyes of textile effluent by microorganisms: an environmentally and economically sustainable approach. European Journal of Microbiology \& Immunology, 9(4):114-118.

Jo-Shu, C. (1989). Kinetic characteristics of bacterial azo dye decolorization by Pseudomonas luteola, Feng Chia University, Taichung, Taiwan, Republic of China.

Kumar, A., Chopra, J. Singh, S. K. Khan, A. \& Singh, R. N. (2016). Biodegradation of azo dyes by Bacillus subtilis RA29‘. Der Pharmacia Lettre, 7(6):234-238. 
Lalnunhlimi, S. \& Veenagayathri, K. (2016). Decolorization of azodyes (Direct Blue 151 and Direct Red 31) by moderately alkaliphilic bacterial consortium. Brazilian Journal of Microbiology, 47:39-46.

Leelakriangsak, M. \& Borisut, S. (2012). Characterization of the decolorizing activity of azo dyes by Bacillus subtilis azoreductase AzoR1. Songklanakarin Journal of Science and Technology, 34(5):509-516.

Liao, C.S., Hung, C.H. \& Chao, S.L. (2013). Decolorization of azo dye reactive black B by Bacillus cereus strain HJ-1. Chemosphere, 90(7):2109-2114.

Lucas, MS., Dias, AA., Sampaio, A., Amaral, C. \& Peres, JA. (2007). Degradation of a textile reactive azo dye by a combined chemical biological process: fenton reagent-yeast. Journal of Water Research, 41:1103-1109.

Madhuri, T., Indrani, V. \& Devi, P. S. (2018). Analytical biodegradation of azo dye (Remazol Red RB) by Bacillus cereus. Journal of Chemical and Pharmaceutical Research, 10(4):74-80.

Mahmood, R., Sharif, F., Ali, S. \& Hayyat, M. U. (2015). Enhancing the decolorizing and degradation ability of bacterial consortium isolated from textile effluent affected area and its application on seed germination. The Scientific World Journal: 628195.

Mishra, V.K. \& Sharma, H. (2014). Decolourization of textile azodyes by Bacillus spp. ICETT2014 International Conference on Emerging Trends in Traditional \& Technical Textiles. Jalandhar, Punjab, India.

Seesuriyachana, P., Takenakab, S., Kuntiyaa, A., Klayraungc, S., Murakamib, S., et al. (2007) Metabolism of Azo Dyes by Lactobacillus casei TISTR 1500 and effects of various factors on decolorization. Journal of Water Research, 41:985 - 992.

Sghaier, I., Guembri, M., Chouchane, H., Mosbah, A., Ouzari, H.I. et al. (2019). Recent advances in textile wastewater treatment using microbial consortia. Journal of Textile Engineering \& Fashion Technology, 5(3):134-146.

Shah, M. P. (2014). Microbial decolorization of reactive azo dyes by Bacillus spp. ETL-1949 under anaerobic condition. International Journal of Environmental Bioremediation \& Biodegradation, 2(1):30-36.

Shah, M. P., Patel K. A. \& Nair, S. S. (2013a). Microbiological removal of crystal violet dye by Bacillus subtilis ETL-2211. OA Biotechnology, 2(2):11.

Shah, M. P., Patel, K. A., Nair, S. S. \& Darji A. M. (2013b). Potential effect of two Bacillus spp on decolorization of azo dye. Journal of Bioremediation \& Biodegradation, 4:7.

Silveira, E. (2003). Selection of Pseudomonas for industrial textile dyes decolourization, DMFA/Cenapesq, Federal Rural University of Pernambuco, UFRPE, Dois Irmãos, Recife-PE, Brazil. 
Sudha, M., Saranya, A., Selvakumar, G. \& Sivakumar, N. (2014). Microbial degradation of Azo Dyes: A review. International Journal of Current Microbiology and Applied Sciences, 3(2):670-690.

Sun, J.H., Sun, S.P., Sun, J. Y., Sun, R. X., Qiao, L. P. et al. (2007). Degradation of azo dye Acid Black 1 using low concentration iron of fenton process facilitated by ultrasonic irradiation. Ultrasonics Sonochemistry, 14:761-766.

Thakur, M. C., Khan, A. \& Doshi, H. (2012). Isolation and screening of dye degrading microorganisms from the effluents of dye and textile industries at Surat. American Journal of Environmental Engineering, 2(6):152-159. 